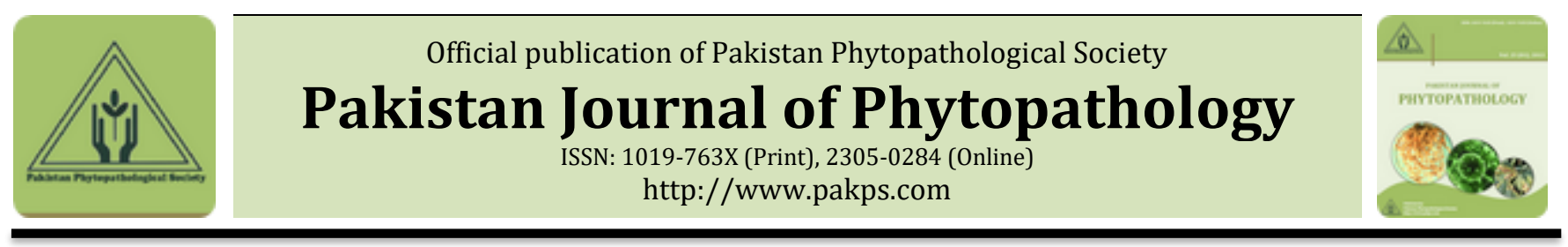

\title{
A CASE STUDY FOR THE OCCURRENCE OF BACTERIAL LEAF SPOT OF MANGO IN PUNJAB (PAKISTAN)
}

\author{
aMuhammad Irfan, aSyed A. H. Naqvi*, aRashida Perveen, bFarah Naz, cAmmarah Hasnain, aSobia Chohan \\ aDepartment of Plant Pathology, FAS\&T, Bahauddin Zakariya University, Multan, Pakistan. \\ ${ }^{b}$ Pir Mehr Ali Shah University of Arid Agriculture, Rawalpindi, Pakistan. \\ cBiological Science Department, Forman Christian College University, Lahore, Pakistan.
}

\begin{abstract}
A B S T R A C T
A survey was conducted for bacterial black spot disease in different districts of Punjab. Maximum disease incidence was observed in Multan followed by Muzaffar Garh and Khanewal while minimum disease incidence was noted in Jhang and Lodhran district of the Punjab. Thirty symptomatic samples were collected from multiple locations and associated pathogens were isolated. Bacterial isolates were inoculated on different mango cultivars to evaluate the level of resistance. None of the cultivar was resistant against the disease although Anwar Ratool and Late Chounsa were least affected. Eighteen isolates were grown on asparagine and nutrient agar with $5 \%$ glucose medium to check their variability which depicted round, convex, creamy white and yellow pigmented colonies with entire margins. Mucoid colony growth was found when inoculated on nutrient agar with $5 \%$ glucose. Biochemical tests showed that all bacterial isolates were gram negative, salt tolerant, oxidase negative and showed negative growth while grown on asparagines medium. On the basis of these tests bacteria were found as $X$. campestris. Although yellow pigmented isolates were found less aggressive as compared to creamy white ones.
\end{abstract}

Keywords: Anacardiaceae, Occurrence, Biological characterization, Mango.

\section{INTRODUCTION}

Mango (Mangifera indica L.) is a vital fruit of family Anacardiaceae grown in tropics and subtropics of the world (Bally, 2006). A large number of marketable products are made by using mango fruits including juices, pickles and acid flavor (Bally, 2006). Mango fruit is a very good source of vitamins and minerals (Ajila and Rao, 2008). Malda, Langra, Dusehri, Sindhri, chaunsa, Anwar Ratool, Fajri and Samar Bahisht are important mango cultivars grown in Pakistan (Ajila and Rao, 2008). Among pathological problems, Mango bacterial black spot (MBBS) caused by Xanthomonas campestris pv. Mangiferae indicae is a disease with high incidence in a number of tropical

Submitted: September, 22, 2017

Revised: December, 22, 2017

Accepted for Publication: December, 23, 2017

* Corresponding Author:

Email: atifhasanshah@hotmail.com

(C) 2017 Pak. J. Phytopathol. All rights reserved. countries. MBBS is a severe necrotic disease of mango (Singh et al., 2004). Most commercial cultivars are highly susceptible to this disease and infection can result in defoliation and drastic reduction in yield and fruit quality, especially when storms or hurricanes are involved. Long distance dissemination occurs through exchange of planting material among countries while short distance dissemination occurs through wind driven rains, irrigation water splashes and use of infected bud wood. Wind speed higher than 6 meter per second can create wounds for infection (Pruvost et al., 1993).

The disease is characterized by lesions development on leaves, twigs and fruits. Leaf lesions are black, raised and tend to be angular in shape as they are confined by the large veins frequently surrounded by yellow margins. Bacterial lesions do not expand with fruit ripening. Old lesions dry and turn brown ash-gray. Twig and stem lesions are black and cracked. The spots on fruit are scabby black often with star shaped cracks and water 
soaked margins. In case of severe infection fruit drop prematurely and less severe infection reduces fruit quality (Pruvost et al., 1993). Young leaves are resistant to pathogen as these do not have functional stomata (Gagnevin and Pruvost, 2001). Microscopic analysis showed that bacteria induce hypertrophy of leaf tissues as a result of enlargement of intercellular spaces of parenchyma due to which epidermis ruptures and bacteria exude from lesion (Gagnevin and Pruvost, 2001). An estimate of bacterial population on mango surface shows that a three month old leaf lesions on a susceptible cultivar contain up to 107 CFUs (colony forming units) while an eighteen month old lesion contain 105 CFUs (Gagnevin and Pruvost, 2001). According to pathological, cultural, biochemical, physiological, serological and genetic data, strains of the pathogen from different production areas are diverse (Sanders et al., 1994; Gagnevin and Pruvost, 2001, 1995; Kishun, 1995, Pruvost et al., 2005). There is great genetic diversity among strains of pathogen from Southeast Asia, suggesting that this region of host diversity is also a centre of pathogen diversification (Gagnevin et al., 1995). The pathogen $(X$. campestris pv. mangiferaeindicae) has a single polar flagellum is Gram-negative, aerobic, non-sporulating, rod shaped and 0.4-0.5 × 1.0-1.5 $\mu \mathrm{m}$ (Manicom et al., 1984). It cannot use asparagine as a sole carbon and nitrogen source, but is able to hydrolyse starch, esculin, gelatin and casein. On artificial media, colonies are cream colored. (The latter trait is atypical for Xanthomonads, which are usually yellow in culture). Yellow pigmented Xanthomonads have also been recovered from mango in Brazil, South Africa and Florida USA. These strains cause non-raised leaf lesions and do not cause fruit or stem lesions, therefore, should not be classified as pv. mangiferaeindicae (Ah-You et al., 2007b). In spite of high level of economic losses (50\%-100\%) no systematic work has been carried out with regard to bacterial black spot of mango in Pakistan. A few scattered reports regarding the presence of certain symptoms on mango plant are available. Hence, there was a dire need to endorse the presence of mango bacterial black spot disease in Pakistan and characterization of local isolates of the pathogen. Since, the current research was aimed for 1) through survey of the mango producing districts of Punjab, Pakistan to record disease incidence 2) to characterize collection of isolates of the bacterium from all the surveyed areas on biochemical, cultural and physiological basis.

\section{MATERIALS AND METHODS}

Study site: The current research was carried out at Department of Plant Pathology, Faculty of Crop and Food Sciences, Pir Mehr Ali Shah, Arid Agriculture University Rawalpindi (33.6468 $\mathrm{N}, 73.0811^{\circ} \mathrm{E}$ ), Pakistan.

Survey for disease incidence and collection of samples from various Districts: Through survey of five Districts of Punjab i.e., Muzaffar-Garh, Multan, Khanewal, Jhang and Lodhran was carried out to determine the incidence of the disease in the orchards. In each district a random selected orchards were visited and the incidence was determined through $\mathrm{X}$ method.

The disease incidence was calculated by the following formula:

Disease incidence $(\%)=\frac{\text { Number of diseased leaves }}{\text { Total number leaves observed }} \times 100$

Thirty disease samples comprising of six samples from each District were collected on the basis of symptoms. Samples were collected from vegetative parts of infected mango plants i.e., leaves and twigs as the mango plant is an evergreen plant and leaves remains on it throughout the year, hence, serve the inoculum source for the next year fruit. Samples were collected in polythene bags and placed in refrigerator at $4^{\circ} \mathrm{C}$. Before processing all the samples were assigned with code names according to their locality or place of collection and mango cultivar from which these were obtained as given (Table 1).

Isolation of pathogen: Bacterial isolation was carried out by using two methods. In first method, leaf tissues or twigs containing lesions were cut down in to small pieces. Cuttings were made in such a way that leaf lesion along with some healthy leaf portion were separated from the leaf. The small pieces were surface sterilized with $1 \%$ Clorox followed by two washings with sterilized distilled water to remove all traces of disinfectant. On drying these pieces were placed on yeast sucrose nutrient agar medium. In second method leaf lesions after surface sterilization were ground in sterilized distilled water with the help of pestle and mortar. The suspension was transferred to sterilized test tubes and left the tubes for 10-15 minutes so that plant debris can be settled down. After that supernatant relatively clear water layer was separated in to a test tube and spread over YPSA plates with the help of a sterilized glass rod. The plates were incubated at $28^{\circ} \mathrm{C}$ for $2-3$ days according to Schaad and Stall (1988). Cuttings from individual samples were processed on separate YSNA plates. Morphologically different colonies from each sample were streaked on separate YSNA plates. 
Pak. J. Phytopathol., Vol. 29 (02) 2017. 247-256

Table 1. Mango bacterial black spot samples their locality and host cultivars

\begin{tabular}{|c|c|c|c|}
\hline S. No. & Locality & Host Cultivar & Isolate Code \\
\hline 1 & Muzaffar Garh (01) & Malda & *MGh1Ma \\
\hline 3 & Muzaffar Garh (03) & Anwar Retool & MGh3 Ar \\
\hline 5 & Muzaffar Garh (05) & Chaunsa & MGh5Ch \\
\hline 6 & Muzaffar Garh (06) & Malda & MGh6Ma \\
\hline 7 & Multan (01) & Anwar Retool & ${ }^{*} \mathrm{Mtn} 1 \mathrm{Ar}$ \\
\hline 10 & Multan (04) & Langra & Mtn4La \\
\hline 11 & Multan (05) & Anwar Retool & Mtn5Ar \\
\hline 12 & Multan (06) & Doshehri & Mtn6Ds \\
\hline 13 & Khanewal (01) & Chaunsa & ${ }^{*} \mathrm{Kwl} 1 \mathrm{Ch}$ \\
\hline 14 & Khanewal (02) & Malda & $\mathrm{Kwl} 2 \mathrm{Ma}$ \\
\hline 15 & Khanewal (03) & Doshehri & Kwl3Ds \\
\hline 20 & Jhang (02) & Chaunsa & Jhg2Ch \\
\hline 21 & Jhang (03) & Langra & Jhg3La \\
\hline 22 & Jhang (04) & Anwar Retool & Jhg4Ar \\
\hline 23 & Jhang (05) & Doshehri & Jhg5Ds \\
\hline 24 & Jhang (06) & Chaunsa & Jhg6Ch \\
\hline 25 & Lodhran (01) & Doshehri & ${ }^{*}$ Ldh1Ds \\
\hline 26 & Lodhran (02) & Chaunsa & Ldh2Ch \\
\hline 27 & Lodhran (03) & Malda & Ldh3Md \\
\hline 28 & Lodhran (04) & Doshehri & Ldh4Ds \\
\hline 29 & Lodhran (05) & Doshehri & Ldh5Ds \\
\hline 30 & Lodhran (06) & Doshehri & Ldh6Ds \\
\hline
\end{tabular}

*MGh= Muzaffar-Garh, *Mtn= Multan, *Kwl=Khanewal, *Jhg=Jhang, *Ldh=Lodhran; *Ma=Malda, *Ds=Doshehri, ${ }^{*} \mathrm{La}=$ Langra, ${ }^{*} \mathrm{Ch}=$ Chaunsa, ${ }^{*} \mathrm{Ar}=$ Anwer retool

Pathogenicity Test: All the isolates that showed the positive response to hypersensitivity test were checked for their pathogencity on highly susceptible mango cultivar i.e., Doshehri. Asymptomatic mango plants of Doshehri cultivar were taken from the local nursery and were used for pathogenicity test. These plants were provided with optimum disease development conditions i.e., temperature and humidity before inoculation of pathogen for the purpose that if any epiphytic survival of bacteria is present or not. After this confirmatory test asymptomatic plants were inoculated with $2 \mathrm{ml}$ of all the bacterial isolates suspended in sterilized distilled water maintaining 0.3 optical density at 460nm (107-108 CFU/ml bacterial cell concentration by using spectrophotometer) with the help of hypodermic sterile syringe. For inoculation purpose relatively older leaves were selected. An equal amount of sterilized distilled water was used as negative control (Quimio, 1992). The plants were kept under polythene bags to maintain high relative humidity and a higher day and lower night temperature. 48-72 hours old bacterial growth on YPSA medium was used for this purpose. Symptom development was observed separately from different colonies of individual isolates. The colonies which produced symptoms were taken as positive for pathogencity.

Hypersensitivity Test: Hypersensitivity test was performed for all isolates (48-72 hours of bacterial growth on YPSA plates) to confirm that either the bacteria are plant pathogenic or not. For this purpose bacterial isolates were suspended in sterilized distilled water by using spectrophotometer at an optical density of 0.3 at 460nm (107-108 CFU/ml bacterial cell concentration) was adjusted. Suspension $2 \mathrm{ml}$ of each isolate was injected in the intercellular spaces of one month old tobacco (Nicotiana tobacum) leaves by using sterilized hypodermic syringe. An equal amount of sterilized distilled water was also injected as negative control. All the plants were kept in green house at $25-30^{\circ} \mathrm{C}$ day and $15-18^{\circ} \mathrm{C}$ night temperature until symptoms were developed. Tobacco leaves showing yellow chlorosis to brown necrosis around the point of injection were taken positive for test (Quimio, 1992). 


\section{Biochemical characterization: Biochemical} characterization of all isolates was done on the basis of five confirmatory tests including gram staining, growth on asparagines medium, growth on nutrient agar with 5\% glucose, salt tolerance test and oxidase test.

Gram Staining: The Gram staining reaction of all bacterial isolates positive for pathogencity was carried out by following the procedure of Schaad and Stall (1988). First of all bacterial smear was thinly spread over a clean slide. After air drying the smear was fixed by rapidly passing the slide over the flame twice or thrice. Now the slide with dried fixed smear was flooded with crystal violet solution for a period of one minute followed by tap water washing for few seconds. Again smear on slide was flooded with iodine for one minute and then rinsed water. This time slide was blot dried and decolorized by adding 95\% ethyl alcohol drop by drop until all the color was washed out. Finally the slide was counter stained with safranin for ten seconds after blot drying. After washing, slide was examined under microscope. The bacterial isolates that produced pink-red end color were characterized as gram negative and those with dark purplish end color were gram positive.

Growth on Asparagine Medium: This diagnostic test was used for Xanthomonas because these were not able to grow on Asparagine medium (Asparagine, 0.5g; $\mathrm{Kh}_{2} \mathrm{PO}_{4}$, $0.1 \mathrm{~g}$; agar, $12-15 \mathrm{~g} ; \mathrm{KNO}_{3}, 0.5 \mathrm{~g} ; \mathrm{CaCl}_{2}, 0.1 \mathrm{~g} ; \mathrm{NaCl}, 0.1 \mathrm{~g}$ and $\mathrm{MgSO}_{4} .7 \mathrm{H}_{2} \mathrm{O}, 0.2 \mathrm{~g}$ in 1 liter distilled water with $\mathrm{pH}-7$ and autoclaved at $121{ }^{\circ} \mathrm{C}$ for 15 minutes) while others like Enterobacteriaceae and many Pseudomonas have the capability to grow on this medium. For this purpose all the positive isolates were allowed to grow on asparagines medium for a period of 2-3 days at a temperature of $28^{\circ} \mathrm{C}$ (Bradbury, 1984). A negative control was taken as uninoculated plates.

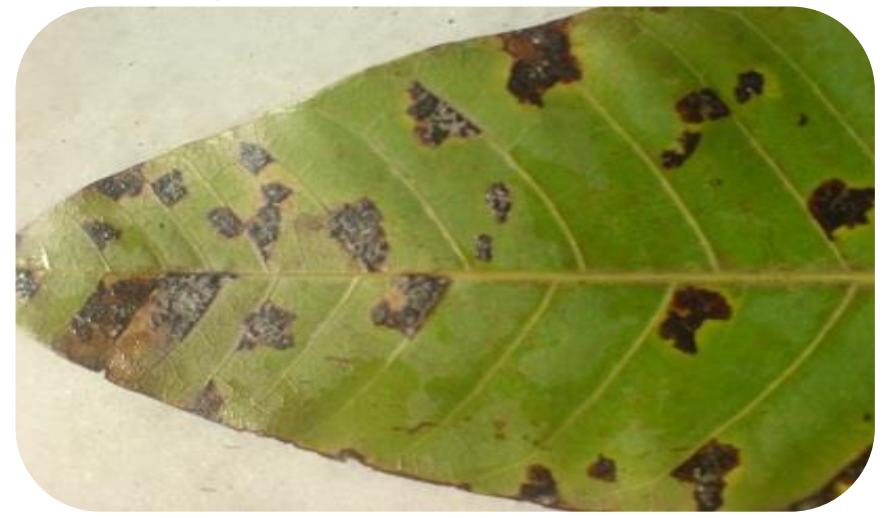

Figure 1. MBBS on leaf area
Nutrient Agar with 5\% Glucose: This test was used to check the variability in colony morphology and to confirm the pathogen as $X$. campestris because this bacterium shows mucoid colony growth on this medium i.e., nutrient agar with 5\% Glucose (Nutrient agar, 23g; Glucose, 5\% dissolved in1 liter of distilled water maintaining the $\mathrm{PH} 7$ and autoclaved at $121{ }^{\circ} \mathrm{C}$ for 15 minutes) while other Xanthomonas species do not show such growth pattern on this medium (Bradbury, 1984). The isolates were streaked on nutrient agar with $5 \%$ glucose medium plates and an incubation period of $48-72$ hours was given at $28^{\circ} \mathrm{C}$.

Salt Tolerance Test: All the Isolates were tested for their salt tolerance ability and inoculated on nutrient broth containing $0 \%, 1 \%, 2 \%, 3 \%, 4 \%$ and $5 \% \mathrm{NaCl}$ (Schaad and Stall, 1988). Salt free broth was used as positive control while an uninoculated broth of each salt concentration was used as negative control. The results were recorded as presence or absence of bacterial growth.

Oxidase Test: Oxidase test was done by rubbing a loopful of bacteria on a filter paper with drops of $1 \mathrm{X}(\mathrm{W} / \mathrm{V})$ aqueous $\mathrm{N}, \mathrm{N}, \mathrm{N}, \mathrm{N}$ - tetra methyl p-phenylenediamine dihydrochloride solution. The isolates were categorized on the basis of time taken for change in color i.e., isolates which developed purple color in 10 seconds were taken as positive, those developed color in 10-60 seconds were taken as slow positive while isolates that taken a time of more than 60 seconds were taken as negative to oxidase test (Dayakar and Gnanamanickam, 1996).

\section{RESULTS}

Isolation of pathogen: A total number of thirty isolates were obtained and purified from thirty (30) samples inoculated on YPSA plates after an incubation period of 24 -72 hours. Two types of colonies were found on the basis of color variability i.e., creamy white and yellow pigmented.

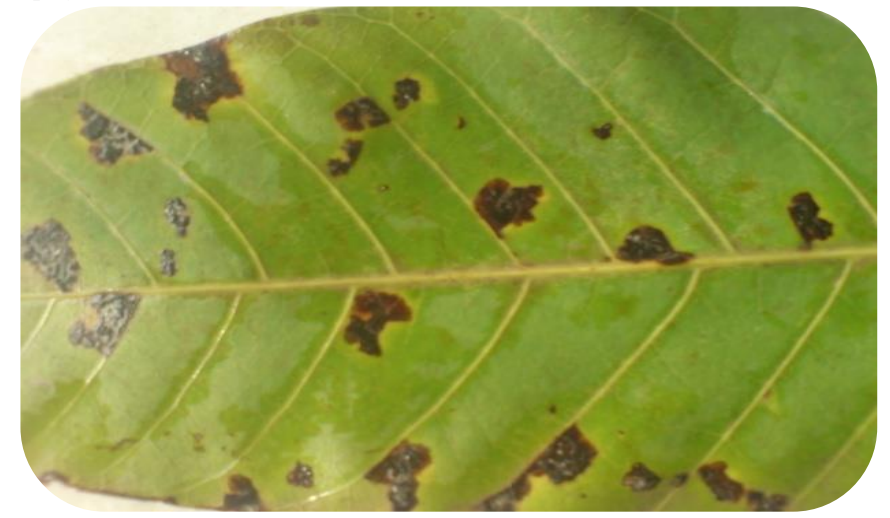




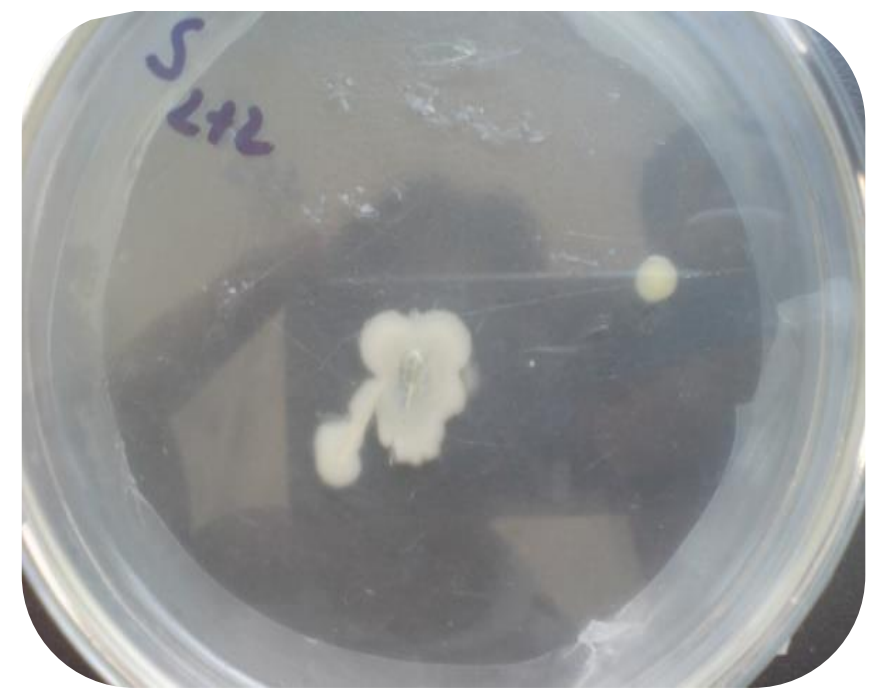

Figure 2. Isolation of Bacterium on YPSA medium

Hypersensitivity test: Tobacco leaves injected with bacterial isolates showed positive reaction for all the isolates within 48-72 hours. Around the injection point a chlorosis type reaction leading to brown necrosis was observed. Creamy white isolates were found more aggressive as compared to yellow pigmented isolates. The creamy white isolates showed deep brown necrosis prior to yellow pigmented

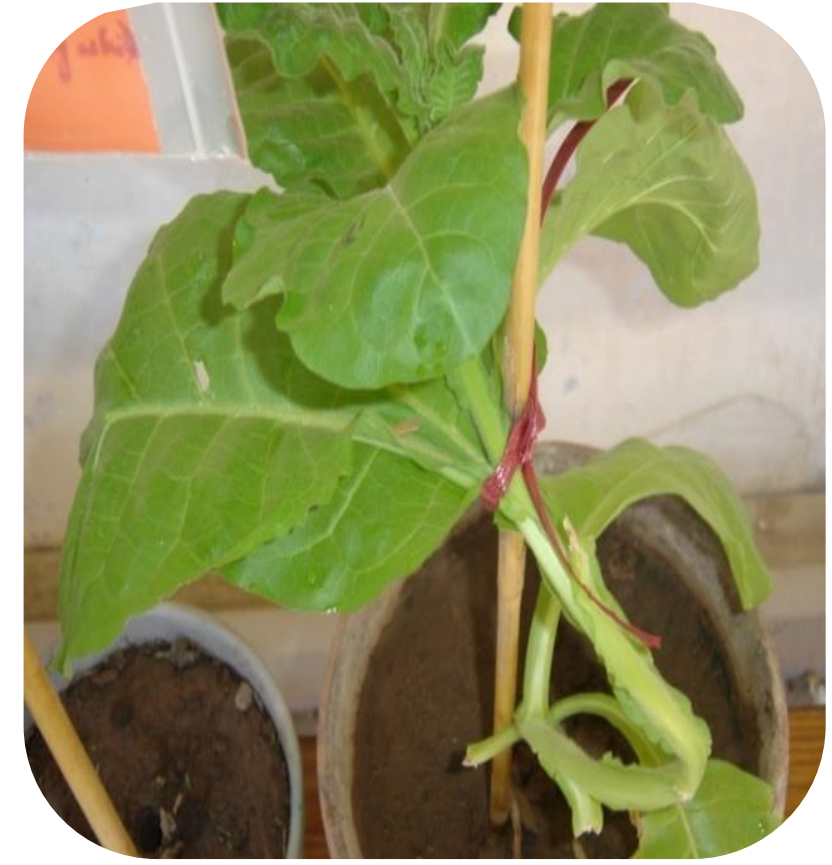

Figure 3. Hypersensitivity response on tobacco plants

Pathogenicity reaction: Out of 30 isolates only 18 were found positive for pathogenicity test. On the whole, variability in disease development was observed between creamy white and yellow pigmented isolates. In case of creamy white isolates, development

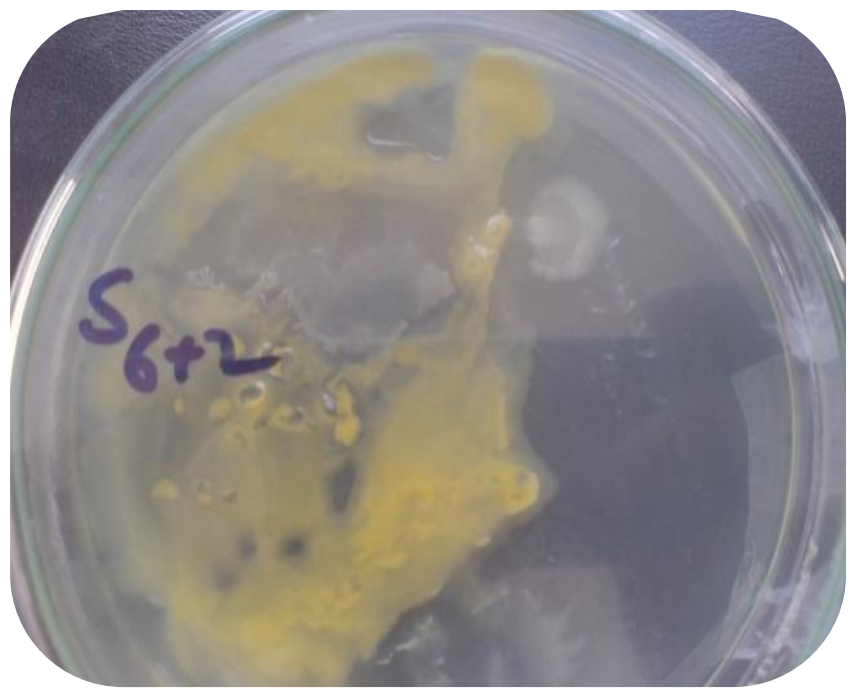

isolates. Tobacco leaves that were inoculated with sterilized distilled water showed no disease symptoms and remain green. It was found that all the thirty bacterial isolates were positive for hypersensitivity and none of the isolates showed the negative reaction. From the hypersensitivity reaction it was clear that all the bacterial isolates were plant pathogenic (Table 2).

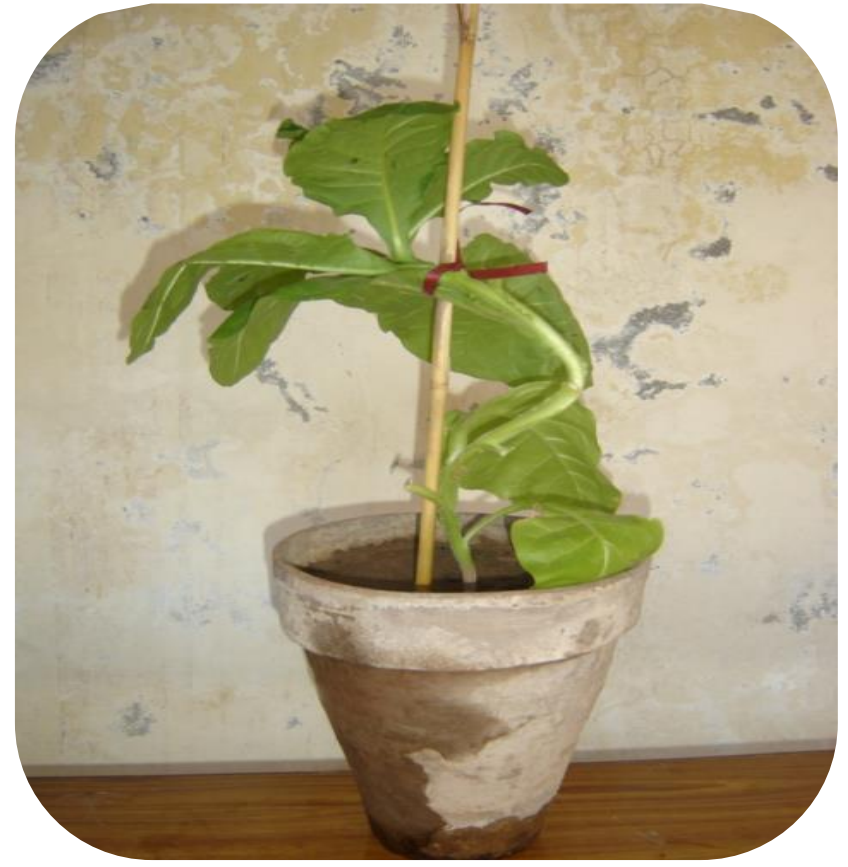

of symptoms was started earlier as compared to yellow pigmented isolates. Also the symptoms produce by creamy white isolate coalesce in most of the cases but in case of yellow pigmented isolates, the spots remained isolated and small (Table 2). 

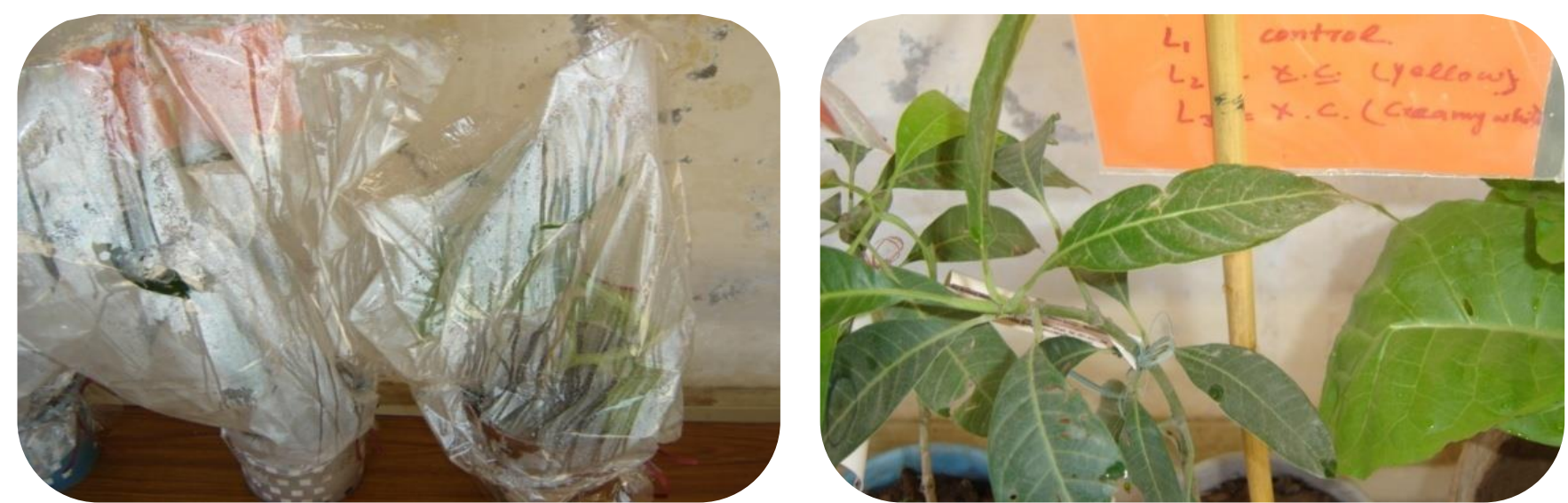

Figure 4. Pathogenicity test of bacterium on mango plants Table 2. Various isolates of bacterium showing hypersensitivity and pathogenicity response

\begin{tabular}{clcc}
\hline Sr. No. & Isolate Code & Hypersensitivity & Pathogenicity \\
\hline 1 & MGh1Ma & + & + \\
2 & MGh2La & + & - \\
3 & MGh3 Ar & + & + \\
4 & MGh4Ds & + & + \\
5 & MGh5Ch & + & - \\
6 & MGh6Ma & + & + \\
7 & Mtn1Ar & + & + \\
8 & Mtn2Ds & + & - \\
9 & Mtn3Ch & + & + \\
10 & Mtn4La & + & - \\
11 & Mtn5Ar & + & + \\
12 & Mtn6Ds & + & + \\
13 & Kwl1Ch & + & + \\
14 & Kwl2Ma & + & + \\
15 & Kwl3Ds & + & - \\
16 & Kwl4Ds & + & + \\
17 & Kwl5Ar & + & - \\
18 & Kwl6La & + & + \\
19 & Jhg1Ma & + & - \\
20 & Jhg2Ch & + & + \\
21 & Jhg3La & + & + \\
22 & Jhg4Ar & + & - \\
23 & Jhg5Ds & + & - \\
24 & Jhg6Ch & + & + \\
25 & Ldh1Ds & + & + \\
26 & Ldh2Ch & + & + \\
27 & Ldh3Md & + & + \\
28 & Ldh4Ds & + & + \\
29 & Ldh5Ds & + & + \\
30 & Ldh6Ds & ther & + \\
\hline
\end{tabular}

Cultural characterization: The isolates which were positive for pathogenicity test were processed for their cultural characterization. It was noted that from all the eighteen isolates processed fifteen isolates were of creamy white color and remaining three isolates showed yellow pigmentation. The presence of Xanthmonadin pigment is usually taken as distinct character for genus
Xanthomonas. Further on the isolates were grown on nutrient agar with $5 \%$ glucose. The isolates showed a slight variation in colony color and growth characters. It was noted that there were colonies with light yellow color which later on become deep yellow in color. Further on all colonies were mucoid which is the characteristic of $X$. campestris (Table 3 and 4). 
Pak. J. Phytopathol., Vol. 29 (02) 2017. 247-256

Table 3. Growth on YPSA (Yeast Peptone Sucrose Agar) Medium

\begin{tabular}{|c|c|c|c|c|c|c|c|}
\hline \multirow{2}{*}{ Sr. No. } & \multirow{2}{*}{ Isolates } & \multicolumn{6}{|c|}{ Colony characteristics } \\
\hline & & Shape & Contouring & Color (after 24-48 hrs) & Color after $48-72$ hours & Margins & ${ }^{*} \mathrm{M} / \mathrm{NM}$ \\
\hline 1 & MGh2La & Round & Convex & CW & CW & *EM & ${ }^{*} \mathrm{M}$ \\
\hline 2 & MGh3Ar & Round & Convex & SG & CW & EM & M \\
\hline 3 & MGh4Ds & Round & Convex & CW & $\mathrm{CW}$ & EM & M \\
\hline 4 & MGh5Ch & Round & Convex & YP & YP & EM & M \\
\hline 5 & MGh6Ma & Round & Convex & SG & CW & EM & M \\
\hline 6 & Mtn1Ar & Round & Convex & CW & CW & EM & M \\
\hline 7 & Mtn2Ds & Round & Convex & *SG & CW & EM & M \\
\hline 8 & Mtn3Ch & Round & Convex & SG & CW & EM & M \\
\hline 9 & Mtn4La & Round & Convex & *YP & YP & EM & M \\
\hline 10 & Mtn5Ar & Round & Convex & SG & CW & EM & $\mathrm{M}$ \\
\hline 11 & Mtn6Ds & Round & Convex & CW & CW & EM & M \\
\hline 12 & Kwl1Ch & Round & Convex & SG & ${ }^{*} \mathrm{CW}$ & EM & M \\
\hline 13 & Jhg2Ch & Round & Convex & CW & CW & EM & M \\
\hline 14 & Jhg3La & Round & Convex & SG & CW & EM & M \\
\hline 15 & Jhg4Ar & Round & Convex & YP & YP & EM & M \\
\hline 16 & Jhg5Ds & Round & Convex & CW & CW & EM & M \\
\hline 17 & Jhg6Ch & Round & Convex & SG & CW & EM & M \\
\hline 18 & Ldh1Ds & Round & Convex & CW & CW & EM & M \\
\hline
\end{tabular}

\begin{tabular}{clllcrcc}
\hline \multirow{2}{*}{ Sr. No. } & \multirow{2}{*}{ Isolates } & \multicolumn{5}{c}{ Colony characteristics } \\
\cline { 3 - 7 } & & Shape & Contouring & Color (after 24-48 hrs) & Color after 48-72 hours & Margins & ${ }^{*}$ M/NM \\
\hline 1 & MGh2La & Round & Convex & CW & CW & EM & NM \\
2 & MGh3Ar & Round & Convex & SG & CW & EM & NM \\
3 & MGh4Ds & Round & Convex & CW & CW & EM & NM \\
4 & MGh5Ch & Round & convex & LP & EM & NM \\
5 & MGh6Ma & Round & Convex & SG & CW & EM & NM \\
6 & Mtn1Ar & Round & Convex & CW & CW & EM & NM \\
7 & Mtn2Ds & Round & Convex & SG & EM & NM \\
8 & Mtn3Ch & Round & Convex & SG & CW & EM & NM \\
9 & Mtn4La & Round & Convex & LP & YP & EM & NM \\
10 & Mtn5Ar & Round & Convex & SG & CW & EM & NM \\
11 & Mtn6Ds & Round & Convex & CW & CW & EM & NM \\
12 & Kwl1Ch & Round & Convex & SG & CW & EM & NM \\
13 & Jhg2Ch & Round & Convex & CW & CW & NM \\
14 & Jhg3La & Round & Convex & SG & YP & EM & NM \\
15 & Jhg4Ar & Round & Convex & LP & CW & EM & NM \\
16 & Jhg5Ds & Round & Convex & CW & CW & EM & NM \\
17 & Jhg6Ch & Round & Convex & SG & CW & EM & NM \\
18 & Ldh1Ds & Round & Convex & CW & N &
\end{tabular}

${ }^{*} \mathrm{EM}=$ Entire Margins, ${ }^{*} \mathrm{CW}=$ Creamy White, ${ }^{*} \mathrm{M}=$ mucoid, ${ }^{*} \mathrm{NM}=$ NonMucoid, ${ }^{*} \mathrm{YP}=$ Yellow Pigmented, *SG=Smoke Grey

Biochemical characterization: All the eighteen by Braudry (1984). Growth on asparagines medium isolates were tested for gram staining reaction. Results was tested for all the isolates and found that none of showed that all the isolates were gram negative with a the isolate was found with positive growth showing pinkish end color of the reaction. All isolates of X. that all of the isolates belong to genus Xanthomonas. campestris were found tolerant against $1 \%, 2 \%$ and $3 \% \quad$ None of the isolates of $\mathrm{X}$. compestris showed change in $\mathrm{NaCl}$ but none of the isolates showed tolerance against color i.e. purple when rubbed on filter paper with drop $4 \%$ and $5 \% \mathrm{NaCl}$. Aspragine medium without any other carbon and nitrogen source was used as diagnostic test for the isolatin of Xanthomonas from Enterobacteriaceae and many Pseudomonas as stated of reagent $(1 \mathrm{X}(\mathrm{W} / \mathrm{V})$ aqueous $\mathrm{N}, \mathrm{N}, \mathrm{N}, \mathrm{N}$ - tetra methyl p-phenylenediamine dihydrochloride) solution. Consequently, oxidase reaction was found negative for all the isolates (Table 5). 
Pak. J. Phytopathol., Vol. 29 (02) 2017. 247-256

Table 5. Findings of the biochemical characterization

\begin{tabular}{lllllll}
\hline Sr. & Isolates & $\begin{array}{l}\text { Gram } \\
\text { No. }\end{array}$ & $\begin{array}{l}\text { Growth on Asparagine } \\
\text { medium }\end{array}$ & $\begin{array}{l}\text { Growth on Nutrient Agar } \\
\text { with 5\% glucose }\end{array}$ & $\begin{array}{l}\text { Salt tolerance } \\
\text { Test }\end{array}$ & $\begin{array}{l}\text { Oxidase } \\
\text { Test }\end{array}$ \\
\hline 1 & MGh2La & - & - & Mucoid & $3 \%$ & - \\
2 & MGh3Ar & - & - & Mucoid & $3 \%$ & - \\
3 & MGh4Ds & - & - & Mucoid & $3 \%$ & - \\
4 & MGh5Ch & - & - & Mucoid & $3 \%$ & - \\
5 & MGh6Ma & - & - & Mucoid & $2 \%$ & - \\
6 & Mtn1Ar & - & - & Mucoid & $3 \%$ & - \\
7 & Mtn2Ds & - & - & Mucoid & $3 \%$ & - \\
8 & Mtn3Ch & - & - & Mucoid & $3 \%$ & - \\
9 & Mtn4La & - & - & Mucoid & $3 \%$ & - \\
10 & Mtn5Ar & - & - & Mucoid & $3 \%$ & - \\
11 & Mtn6Ds & - & - & Mucoid & $2 \%$ & - \\
12 & Kwl1Ch & - & - & Mucoid & $2 \%$ & - \\
13 & Jhg2Ch & - & - & Mucoid & $3 \%$ & - \\
14 & Jhg3La & - & - & Mucoid & $3 \%$ & - \\
15 & Jhg4Ar & - & - & Mucoid & $3 \%$ & - \\
16 & Jhg5Ds & - & - & Mucoid & $3 \%$ & - \\
17 & Jhg6Ch & - & - & Mucoid & - & - \\
18 & Ldh1Ds & - & - & Mucoid & - & \\
\hline
\end{tabular}

Overall disease incidence of mango bacterial black spot Lodhran district of the Punjab. However, it is very much in Punjab: Maximum disease incidence was observed in clear that the disease is prevailing in the orchards of the Multan followed by MuzaffarGarh and Khanewal while Punjab and it may be a reason of low yield and deteriorated minimum disease incidence was noted in Jhang and quality in future in mango orchard (Figure 5).

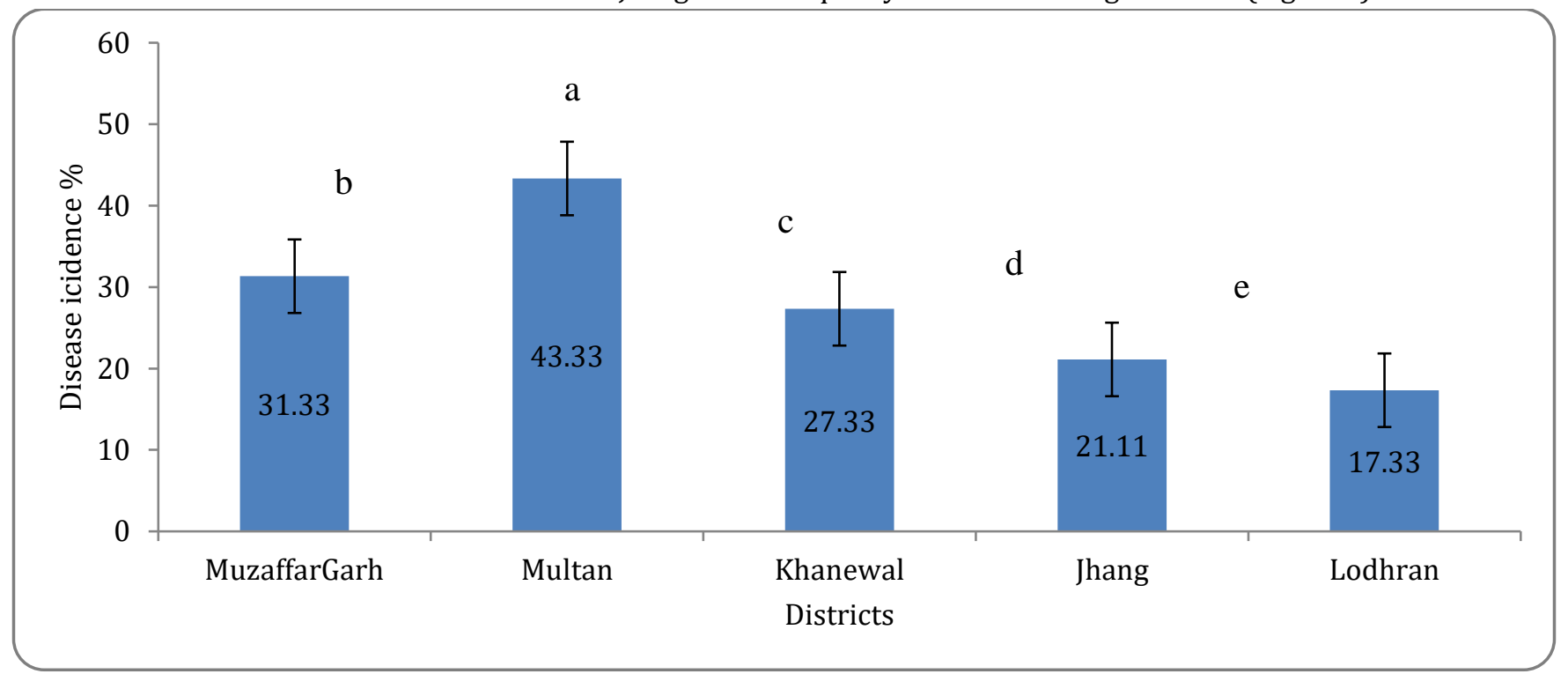

Figure 5. Overall incidence of MBBS in various districts of Punjab

\section{DISCUSSION}

Pakistan is blessed with such an agro ecological conditions that a large number of crops and fruits can be grown in this climatic region. Among fruits mango is the second most leading fruit after kinnow and also called as the king of fruits due to its unique taste, secondary products and nutritional values. Punjab and Sind providences of Pakistan are among the major contributors of mango. During the last decades mango plant has been suffering from a lot of pathological problems due to which its export and production has been suffered badly instead of increasing the area under cultivation. Among the pathological problems bacterial black spot of mango is an important disease reported from different countries of the world including Pakistan. But none of the systematic work has been done on this 
disease rather than few scattered reports of disease occurrence. Bacterial black spot of Mango has been reported from all mango growing areas of the world, such as in Australia, Myanmar, Comoros, India, Japan, Kenya, Malaysia, Mauritius, New Caledonia, Pakistan, Philippines, Rodrigues, Taiwan, South Africa, United Arab Emirates (UAE) and Thailand (Fukuda et al., 1990; Pruvost et al., 1992; Prakash et al., 1994; Gagnevin and Pruvost, 1995, Kishun, 1995; Ah-You et al., 2007b). First documented proof of bacterial black spot disease of mango was given by Doidge (1915). In his work symptoms produced by pathogen on mango plant, its mode of dissemination i.e. wind driven rains were described. Regarding control measures certain spraying experiments of bordeaux mixture and iron sulphide were used but found them useless.

Two types of colonies were found on the basis of color variability i.e., creamy white and yellow pigmented. Colonies with creamy white color have been reported from all the countries from where bacterial black spot disease has been reported while yellow pigmented colonies are reported from Brazil, Florida, Reunion and South Africa. Creamy white strains have already been found more aggressive than yellow pigmented in causing disease (Gagnevin et al., 1997). All the colonies were round, convex and with entire margins. Mucoid colony growth was found when inoculated on nutrient agar with $5 \%$ glucose. Further biochemical tests showed that all the bacterial isolates were gram negative, salt tolerant, oxidase negative and showed negative growth while grown on asparagines medium. On the basis of these tests the bacteria was found as $X$. Campestris. Although yellow pigmented isolates were found less aggressive as compared to creamy white ones.

Different commercially grown mango cultivars were also tested for their susceptibility to pathogen and found that none of the cultivar was resistance against the pathogen although Anwar Ratol and Late Chounsa were the cultivars with comparatively least infection. The presence of Xanthmonadin pigment is usually taken as distinct character for genus Xanthomonas. However, as stated by Bradbury (1984), the absence of pigment does not exclude the isolate from the genus. There could also be possibility of losing the pigment during culturing or the isolate might not carry the character. The gram negativity of the pathogen is in confirmation with the results of Manicom and wallis (1984). Aspragine medium without any other carbon and nitrogen source was used as diagnostic test for the isolatin of Xanthomonas from Enterobacteriaceae and many Pseudomonas as stated by Braudry (1984). All isolates of X. campestris were found tolerant against $1 \%, 2 \%$ and $3 \% \mathrm{NaCl}$ but none of the isolates showed tolerance against $4 \%$ and $5 \% \mathrm{NaCl}$. Results of the present study were found cognizant with the previous findings of Pruvost et al. (1998). Maximum disease incidence was observed in Multan followed by MuzaffarGarh and Khanewal while minimum disease incidence was noted in Jhang and Lodhran district of the Punjab. However, it is very much clear that the disease is prevailing in the orchards of the Punjab and it may be a reason of low yield and deteriorated quality in future in mango orchard. Previous studies have also confirmed that no mango orchard is free from the infestations bacterial black spot.

\section{CONCLUSION}

It is evident from the current research that mango bacterial black spot is prevailing in the orchard of the Punjab and it will not only hamper the crop yield but also the quality of the crop.

\section{ACKNOWLEDGMENT}

Special thanks are due to Dr. Irfan ul Haque and Dr. Faisal Sohail Fateh for their timely help, sympathetic behavior during the course of research work. This manuscript is a part of thesis of Mr. Muhammad Irfan submitted to the Department of Plant Pathology PMAS AAUR.

\section{REFERENCES}

Ah-You, N., L. Gagnevin, O. Pruvost, N. T. Myint and G. I. Johnson. 2007. First Report in Myanmar of Xanthomonas axonopodis pv. Mangiferae indicae Causing Mango Bacterial Canker on Mangifera indica. Plant Disease, 91: 1686-1686.

Ajila, C. M. and U. J. S. Prasada Rao. 2008. Protection against hydrogen peroxide induced oxidative damage in rat erythrocytes by Mangifera indica L. peel extract. Food and Chemical Toxicology, 46: 303-309.

Bally, I. 2006. Species profiles for pacific island agroforestry. Permanent Agricultural Resources (PAR)[Electronic resource].-2006.-URL: http://www. agroforestry. net/images/pdf.

Dayakar, B. and S. Gnanamanickam. 1996. Biochemical and pathogenic variation in strains of Xanthomonas campestris pv. Mangiferae indicae from Southern India. Indian Phytopathology, 49: 
227-233.

Doidge, E. 1915. A bacterial disease of the mango. Bacillus mangiferae N.SP. Annals of Applied Biology, 2: 1-45.

Fukuda, T., K. Uehara, K. Azegami, H. Tabei and K. Nishiyama. 1990. Bacterial canker of mango in Japan caused by Xamthomonas campestris pv. Mangiferae indicae. Japanese Journal of Phytopathology, 56: 474-480.

Gagnevin, L. and O. Pruvost. 2001. Epidemiology and Control of Mango Bacterial Black Spot. Plant Disease, 85: 928-935.

Gagnevin, L., J. E. Leach and O. Pruvost. 1997. Genomic Variability of the Xanthomonas Pathovar mangiferae indicae, Agent of Mango Bacterial Black Spot. Applied and environmental microbiology, 63: 246-253.

Kishun, R. 1995. Detection and management of Xanthomonas campestris pv. Mangiferae indicae. Detection of Plant Pathogens and Their Management: 173-182.

Mahattanatawee, K., J. A. Manthey, G. Luzio, S. T. Talcott, K. Goodner and E. A. Baldwin. 2006. Total Antioxidant Activity and Fiber Content of Select Florida-Grown Tropical Fruits. Journal of Agricultural and Food Chemistry, 54: 7355-7363.

Manicom, B. Q. and F. M. Wallis. 1984. Further Characterization of Xanthomonas campestris pv. Mangiferae indicae. International Journal of Systematic Bacteriology, 34: 77-79.

McClung, L. S. 1985. Bergey's Manual of Systematic Bacteriology, Volume 1.: Edited by Noel R. Krieg. The Williams \& Wilkins Co., Baltimore, 1984, 964 pp. $\$ 80.00$. International Journal of Systematic Bacteriology, 35: 408-408.

Prakash, O., A. Misra and M. Raoof. 1994. Studies on mango bacterial canker disease. Bio. Memoirs, 20:
95-107.

Pruvost, Couteau, Perrier and Luisetti. 1998. Phenotypic diversity of Xanthomonas sp. mangiferae indicae. Journal of Applied Microbiology, 84: 115-124.

Pruvost, O., A. Couteau and J. Luisetti. 1992. Pepper Tree (Schinus terebenthifolius Radii), a New Host Plant for Xanthomonas campestris pv. Mangiferae indicae. Journal of Phytopathology, 135: 289-298.

Pruvost, O., A. Couteau, C. Verniere and J. Luisetti. 1993. Epiphytic Survival of Xanthomonas campestris pv. Mangiferae indicae on Mango Buds. Acta Horticulturae: 337-344.

Pruvost, O., A. couteau, X. perrier and J. Luisetti. 1995. Phenotypic diversity of Xanthomonas sp. mangiferae indicae. Journal of Applied Microbiology, 84:115-124.

Quimio, J.A. 1992. Annual report of the plant pathologist: July 17,1991 to July 16,1992. Enset Team Support Project Sidamo GamoGofa. Peasants Agricultural Development Program-PADEPIII. Awasa Research Center (IAR). Awasa, Ethiopia.

Sanders, G. M., J. A. Verschoor, S. van Wyngaard, L. Korsten and J. M. Kotzé. 1994. Production of monoclonal antibodies against Xanthomonas campestris pv. Mangiferae indicae and their use to investigate differences in virulence. Journal of Applied Bacteriology, 77: 509-518.

Schaad, N. W., J. B. Jones and W. Chun. 2001. Laboratory guide for the identification of plant pathogenic bacteria. American Phytopathological Society (APS Press).

Singh, U. P., D. P. Singh, M. Singh, S. Maurya, J. S. Srivastava, R. B. Singh and S. P. Singh. 2004. Characterization of phenolic compounds in some Indian mango cultivars. International Journal of Food Sciences and Nutrition, 55: 163-169. 